Reraiven by 981

OCT 151980

NUREG/CR-4125

PNL-5374

BHARC-300/85/002

Vol. 1, Rev. 1

\title{
Guidelines and Workbook for Assessment of Organization and Administration of Utilities Seeking Operating License for a Nuclear Power Plant
}

Guidelines for Utility Organization and Administration Plan

Prepared by J. A. Thurber, J. Olson, R. N. Osborn, P. Sommers, R. D. Widrig/BHARC

Battelle Human Affairs Research Centers

Pacific Northwest Laboratory

Prepared for

U.S. Nuclear Regulatory

Commission

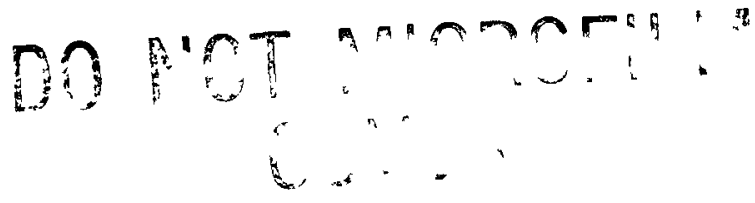




\section{NOTICE}

This report was prepared as an account of work sponsored by an agency of the United States Government. Neither the United States Government nor any agency thereof, or any of their employees, makes any warranty, expressed or implied, or assumes any legal liability of responsibility for any third party's use, or the results of such use, of any information, apparatus. product or process disclosed in this report, or represents that its use by such third party would not infringe privately owned rights.

\section{NOTICE}

\section{Availability of Reference Materials Cited in NRC Publications}

Most documents cited in NRC publications will be available from one of the following sources:

1. The NRC Public Document Room, 1717 H Street, N.W. Washington, DC 20555

2. The Superintendent of Documents, U.S. Government Printing Office, Pust Office Box 37082. Washington, DC 20013-7082

3. The National Technıcal Information Service, Springfield, VA 22161

Although the listing that follows represents the majority of documents cited in NRC publications, it is not intended to be exhaustive.

Referenced documents available for inspection and copying for a fee from the NRC Public Docu ment Room include NRC correspondence and internal NRC memoranda; NRC Office of Inspection and Enforcement bulletins, circulars, information notices, inspection and investigation notices; Licensee Event Reports; vendor reports and correspondence; Commission papers; and applicant and licensee documents and correspondence.

The following documents in the NUREG series are available for purchase from the GPO Sales Program: formal NRC staff and contractor reports, NRC-sponsored conference proceedings, and NRC booklets and brochures. Also available are Regulatory Guides, NRC regulations in the Code of Federal Regulations, and Nuclear Regulatory Commission /ssuances.

Documents available from the National Technical Information Service include NUREG series reports and technical reports prepared by other federal agencies and reports prepared by the Atomic Energy Commission, forerunner agency to the Nuclear Regulatory Commission.

Documents available from public and special technical libraries include all open literature items, such as books, journal and periodical articles, and transactions. Federal Register notices, federal and state legislation, and congressional reports can usually be obtained from these libraries.

Documents such as theses, dissertations, foreign reports and translations, and non-NRC conference proceedings are available for purchase from the organization sponsoring the publication cited.

Single copies of NRC draft reports are available free, to the extent of supply, upon written recjuest to the Division of Technical Information and Document Control, U.S. Nucledr Regulatory Com mission, Washington, DC 20555.

Copies of industry codes and standards used in a substantive manner in the NRC regulatory process are maintained at the NRC Library, 7920 Norfolk Avenue, Bethesda, Maryland, and are available there for reference use by the public. Codes and standards are usually copyrighted and may be purchased from the originating organization or, if they are American National Standards, from the American National Standards Institute, 1430 Broadway, New York, NY 10018. 


\section{DISCLAIMER}

This report was prepared as an account of work sponsored by an agency of the United States Government. Neither the United States Government nor any agency Thereof, nor any of their employees, makes any warranty, express or implied, or assumes any legal liability or responsibility for the accuracy, completeness, or usefulness of any information, apparatus, product, or process disclosed, or represents that its use would not infringe privately owned rights. Reference herein to any specific commercial product, process, or service by trade name, trademark, manufacturer, or otherwise does not necessarily constitute or imply its endorsement, recommendation, or favoring by the United States Government or any agency thereof. The views and opinions of authors expressed herein do not necessarily state or reflect those of the United States Government or any agency thereof. 


\section{DISCLAIMER}

Portions of this document may be illegible in electronic image products. Images are produced from the best available original document. 
NUREG/CR--4125-Vo1.1-Rev. 1

TI87 000741
NUREG/CR-4125

PNL-5374

BHARC-300/85/002

Vol. 1, Rev. 1

\section{Guidelines and Workbook for Assessment of Organization and Administration of Utilities Seeking Operating License for a Nuclear Power Plant}

\section{Guidelines for Utility Organization and Administration Plan}

Manuscript Completed: June 1985

Date Published: September 1986

Prepared by

J. A. Thurber, J. Olson, R. N. Osborn, P. Sommers, R. D. Widrig, BHARC

Battelle Human Affairs Research Centers

Seattle, WA 98105

Pacific Northwest Laboratory

Richland, WA 99352

\section{Prepared for}

Division of Human Factors Technology

Office of Nuclear Reactor Regulation

U.S. Nuclear Regulatory Commission

Washington, DC 20555

NRC FIN B2360

\section{DISCLAIMER}

This report was prepared as an account of work sponsored by an agency of the United States Government. Neither the United States Government nor any agency thereof, nor any of their employees, makes any warranty, express or implied, or assumes any legal liability or responsibility for the accuracy, completeness, or usefulness of any information, apparatus, product, or process disclosed, or represents that its use would not infringe privately owned rights. Reference herein to any specific commercial product, process, or service by trade name, trademark, manufacturer, or otherwise does not necessarily constitute or imply its endorsement, recommendation, or favoring by the United States Government or any agency thereof. The views and opinions of authors expressed herein do not necessarily state or reflect those of the United States Government or any agency thereof.

\section{This document does not contain new requirements.}


This report was prepared as an account of work sponsored by an agency of the United States Government Neither the United States Government nor any agency thereof, or any of their employees, makes any warranty, expressed or implied or assumes any legal liability of re sponsibility for any third party's use, or the results of such use, of any information, apparatus, product or process disclosed in this report, or represents that its use by such third party would not infringe privately owned rights

Avallability of Reference Materials Cited in NRC Publicatıons

Most documents cited in NRC publications will be available from one of the following sources

1 The NRC Public Document Room, 1717 H Street, N W Washington, DC 20555

2. The NRC/GPO Sales Program, U S. Nuclear Regulatory Commission, Washington, DC 20555

3. The National Technical Information Service, Springfield, VA 22161

Although the listing that follows represents the majority of documents cited in NRC publications, It is not intended to be exhaustive

Referenced documents avallable for inspection and copying for a fee from the NRC Public Docu ment Room include NRC correspondence and iriternal NRC memoranda, NRC Office of Inspection and Enforcement bulletins, circulars, information notices, inspection and invesigation notices, Licensee Event Reports, vendor reports and correspondence, Commission papers, and applicant and licensee documents and corr espondence

The following documents in the NUREG series are avallable for purchase from the NRC/GPO Sales Program formal NRC staff and contractor reports, NRC sponsored conference proceedings, and NRC booklets and brochures Also avaliable are Regulatory Guides, NRC regulations in the Code of Federal Regulations, and Nuclear Regulatory Commission /ssuances

Documents avallable from the National Technical Information Service include NUREG series reports and technical reports prepared by other federal agencies and reports prepared by the Atomic Energy Commission, forerunner agency to the Nuclear Regulatory Commission

Documents avalable from public and special technical libraries include all open literature items, such as books, journal and periodical articles, and transactions Federal Register notices, federal and state legislation, and congressional reports can usually be obtained from these libraries

Documents such as theses, dissertations, foreign reports and translations, and non NRC conference proceedings are available for purchase from the organization sponsoring the publication cited

Single copies of NRC draft reports are avalable free upon written request to the Division of Tech nical Information and Document Control, U S Nuclear Regulatory Commission, Washington, DC 20555

Copies of industry codes and standards used in a substantive manner in the NRC regulatory process are maintained at the NRC Library, 7920 Norfolk Avenue, Bethesda, Maryland and are avallable there for reference use by the public Codes and standards are usually copyrighted and may be purchased from the originating organization or, if they are American National Standards, from the American National Standards Institute, 1430 Broadway New York NY 10018 


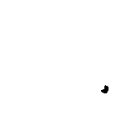




\section{PREFACE}

This revision of Guidelines for Utility Organization and Administration Plan, NUREG/CR-4125, Vol. 1, Rev. T, contains no substantive changes from the first edition. 
, 


\section{ABSTRACT}

Volumes 1 and 2 of this report are a partial response to the requirements of Item I.B.1.1 of the "NRC Action Plan Developed as a Result of the TMI-2 Accident," NUREG-0660, and are designed to serve as a basis for replacing the earlier NUREG-0731, "Guidelines for Utility Management Structure and Technical Resources." These Guidelines are intended to provide guidance to the user in preparing a written plan for a proposed nuclear organization and administration. The purpose of the Workbook (Vol.2) is to guide the NRC reviewer through a systematic review and assessment of a proposed organization and administration. It is the NRC's intention to incorporate these Guidelines and Workhook into a future revision of the Standard Review Plan (SRP), NUREG-0800. However, at this time the report is being published so that the material may be used on a voluntary basis by industry to systematically prepare or evaluate their organization or administration plans. Use of the report by the NRC would not occur until after it has been incorporated in the SRP. 

Executive Summary

Guidelines and Workbook for Assessment of Organization and Administration of Utilities Seeking Operating License for a Nuclear Plant, NUREG/CR-4125 consists of two volumes:

Volume 1: Guidelines for Utility Organization and Administration Plan

Volume 2: Workbook for Assessment of Organization and Administration

This report was prepared by the Battelle Pacific Northwest Laboratories (PNL) under contract to the U.S. Nuclear Regulatory Commission. The report is a partial response to the requirements of Item I.B.1.1 of the "NRC Action Plan Developed as a Result of the TMI-2 Accident," NUREG-0660, and is designed to serve as a basis for replacing the earlier NUREG-0731, "Guidelines for Utility Management Structure and Technical Resources."

It is the NRC's intention to incorporate these Guidelines and Workbook into a future revision of the Standard Review Plan (SRP), NUREG-0800. However, at this time the report is being published as a report of government sponsored work so that the material may be used on a voluntary basis by industry to systematically prepare or evaluate their organization or administration plans. Use of the report by the NRC would not occur until after it has been incorporated in the SRP.

Volume 1: Guidelines for Utility Organization and Administration Plan.

The Guidelines are intended to provide guidance to the user in preparing a written plan for a proposed nuclear organization and administration. The Guidelines allow for individual approaches to organizational structures to account for differences in plant size, number of operating units, number of plant sites, and the individual utility approach to providing technical support. These unique approaches, however, should meet the criteria of a reasoned, fully developed, and logically consistent focus on the user's organization in terms of organization of work, policies and procedures, staffing, and external relationships. The Guidelines contain the following specific elements:

- The definition of key organization and administrative terms;

- A list of information required of license applicants in written form and for the site visit; and

- The acceptance criteria for the utility's organization and administration plan.

Volume 2: Workbook for Assessment of Organization and Administration.

The purpose of the Workbook is to guide the NRC reviewer through a systematic review and assessment of a proposed organization and administration. The Workbook outlines criteria for evaluating a written organization/administration plan and ensures consistent and 
comprehensive review of organization plans and site visit materials. The Workbook is designed to be useful in three principal ways:

(1) By providing descriptions of the basic terms used in the guidelines and description of the literature review that provides additional information on these concepts;

(2) By outlining a process for the review and assessment of an organization plan with attention to site visit activity; and

(3) By providing a protocol for assessing a proposed written organization plan.

The Workbook is designed to assist the NRC reviewer in assembling and analyzing objective information deemed necessary for judging acceptability of the plan, but it does not itself make the judgment. 


\section{ACKNOWLEDGMENTS}

The authors appreciate the assistance and/or reviews provided by the following individuals: F. Al lenspach, H. Booher, V. Boyer, R.J. Cole, P. Connor, L. Crocker, L.L. Cummings, L. Everett, K. Katterman,

A.A. Marcus, P. Mclaughlin, M.V. Nadel, N. Ped, C. Perrow, W. Russell, W. Scott, E. Shen, S. Smith, J. Sutherland, and K. Wilson. 

PREFACE

ABSTRACT

EXECUTIVE SUMMARY

ACKNOWLEDGMENTS

\subsection{INTRODUCTION}

1.1 Summary and Background

1.2 Purpose

1.3 Scope

1.4 Development of Guideitines

1.5 Approach of Guidel ines

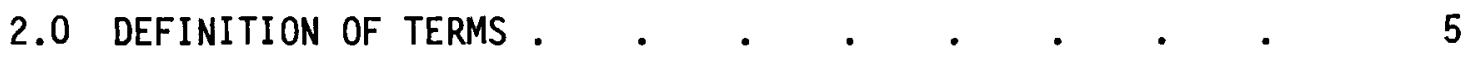

2.1 Organizational Levels of the Applicant . . . 5

2.1.1 The Utility Level . . . . . . . 5

2.1.2 The Nuclear Level . . . . . . . 5

2.1 .3 The Plant Level . $\quad . \quad$. $\quad$. $\quad$. 5

2.2 Organization and Administration . . . . 5

2.2.1 The Organization of Work . . . . . 6

2.2.2 Policies or Procedures. $. \quad . \quad$. $\quad . \quad 6 \quad 6$

2.2 .3 Staffing $. \quad . \quad . \quad . \quad . \quad 6$

2.2.4 External Relationships: $: \quad \cdot \quad \cdot \quad \cdot \quad 6$

3.0 INFORMATION TO BE PROVIDED BY APPLICANTS $\quad . \quad$. $\quad . \quad 7$

3.1 The Organization of Work . . . . . . . 7

3.2 Policies or Procedures . . . . . . . . . .

3.3 Staffing . . . . . . . . . . 9

3.4 External Relationships $\quad . \quad$. $\quad . \quad$. $\quad . \quad$. 10

4.0 ACCEPTANCE CRITERIA FOR GUIDELINES ..$\quad$. . . . 11

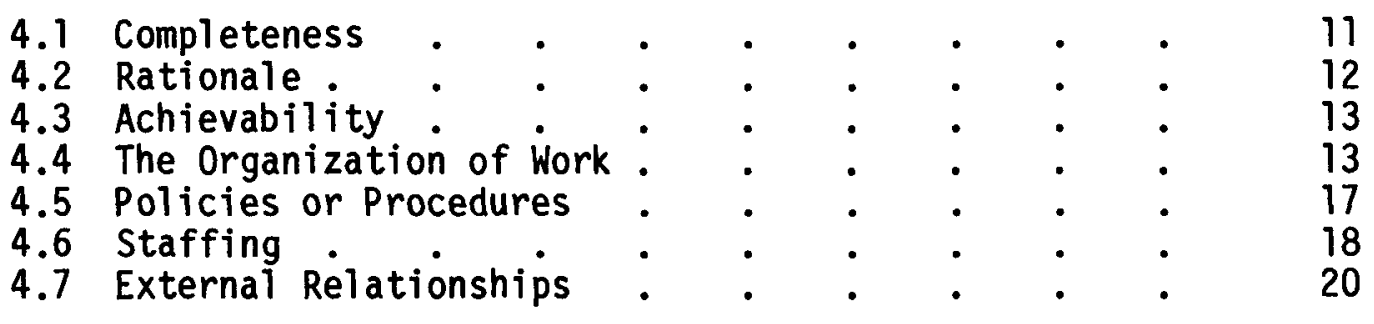

APPENDIX A: ORGANIZATION CHART GUIDELINES . • . . . A-1

APPENDIX B: UTILITY GUIDELINES DOCUMENTS FROM ANSI/ANS . B-1 


\subsection{INTRODUCTION}

\subsection{Summary and Background}

This document outlines guidelines concerning organization and administration for utilities seeking an operating license for a nuclear power plant. For the NRC to assess a utility's organization and administration to protect public health and safety, the Nuclear Regulatory Conmission (NRC) requires submission to an organization and administration plan (OAP) with each license application. The plan will be submitted to the Office of Nuclear Regulation of the NRC. In addition to a written plan, a site visit may be part of the hasis for the licensing decision in the organization and administration area. To ensure consistent and comprehensive review of organization plans, a companion assessment workbook has heen developed for NRC staff use (see NRC, Workbook for Assessment of Organization and Administration of Utilities Seeking operating License for a Nuclear Power Plant).

Analyses of the Three Mile Island (TMI) nuclear plant accident, and subsequent studies of nuclear plant operations by industry, the NRC, and others, suggest that utility organization and administration are key elements to the safe operation of nuclear power plants. In response to TMI Action Plan item I.B.1.1., the NRC staff developed draft NUREG-0731, Guidelines for Utility Management Structure and Technical Resources, dated September, 1980. NUREG-0731 draft guidelines have heen used since then as an adjunct to the Standard Review Plan (Sections 13.1.1, and 13.1.2) for staff reviews of administration and resource capabilities at utilities applying for an operating license (Applicants). Assessments of these license reviews suggested that a complete re-examination of the entire subject should be undertaken. This document replaces NUREG-0731.

\subsection{Purpose}

The primary purposes of this document are (a) to provide guidelines for use by an applicant in developing a written submission to the NRC concerning its proposed organization and administration and (b) to outline criteria for evaluating the applicant's written plan and possible site visits. A site visit may be made by the NRC to clarify the organization and administration information presented in the written plan.

\subsection{Scope}

The review for an operating license will cover the applicant's proposed organization and administration that will be in place to provide support for plant operation.

Most of the operating license review proceeds on a function-by-function basis (e.g., quality assurance and emergency response, among others). In contrast, this document is addressed to concerns of the proposed operation as a whole rather than just to the specific functions. Since the applicant already submits much of what this document calls an OAP for specific functional areas, the applicant may reference prior submittals to 
the NRC regarding specific functional areas. The OAP should discuss how specific functions fit together.

The Division of Human Factors Safety, Office of Nuclear Reactor Regulation, will coordinate the overall organization and administration evaluation with evaluations conducted by various branches concerning the organization and administration of specific functions as follows: the Emergency Preparedness Licensing Branch (EPLB) reviews the acceptability of the emergency organization as part of its primary review responsibility for SRP Section 13.3; the Quality Assurance Branch (QAB) reviews the acceptability of the detailed quality assurance organization as part of its primary review responsibility for SRP Section 17.0; and the Radiological Assessment Branch (RAB) reviews the acceptability of the radiation protection organization as part of its primary review responsibility for SRP Section 12.5. The acceptance criteria necessary for the specific function reviews and their methods of application are contained in the referenced SRP sections.

\subsection{Development of Guidelines}

These guidelines were developed following extensive literature reviews, consideration of the organization and administration assessment requirements in the regulations, and the post-licensing assessments conducted by NRC's Office of Inspection and Enforcement and by the Institute of Nuclear Power Operations.

This document highlights the importance of an applicant's organizational capabilities and its planned use of resources. In particular, it focuses on the applicant's organization in terms of organization of work, policies or procedures, staffing, and external relationships related to safe nuclear power plant operations. Many items contained in these guidelines represent an application of the nuclear power plant experience and the organizational research literature related to efficient and safe operations. However, the literature focuses mostly on work settings other than nuclear power plants. Consequently, future research may lead to revisions of these guidelines as more evidence accumulates about organization and administration of nuclear power plants.

\subsection{Approach of Guidel ines}

No single best method of organization and administration for nuclear power plants has emerged from the nuclear utility experience. Nuclear utilities differ in terms of (1) size, number, and location of plants/stations; (2) financial, economic, and state regulatory climates; and (3) experience in operating nuclear plants. These and other factors prevent the development of an industry-wide, uniform pattern of administration and organization. Thus, the NRC provides the applicant the opportunity to develop a unique administrative and organization pattern which will meet the applicant's overall needs, including the need for safe operations of nuclear power plant(s). Thus, there is no comprehensive checklist of prescriptions for some ideal type of organization and administration in this document. A number of specific organization and administration 
prescriptions are outlined in Section 4.0. The rest of this document is based on the presumption that applicants should have a reasoned, fully developed, and logically consistent plan of overall organization and administration. The basic principle behind the NRC evaluation is that the generation of a reasoned, fully developed, and logically consistent plan is itself evidence of sound administration and organization.

Most of the material covered in these guidelines should be included in the utility's written plan which is to describe its proposed organization and administration. Other material may be obtained by the NRC during a site visit at which time the utility should be prepared to discuss its rationale underlying the proposed organization and administration. These guidelines suggest which material should be in written form and which may be obtained during the site visit and follow-up by the NRC.

To assist the applicant in preparing for a site visit and the written plan for the proposed organization and administration of the nuclear power plant, these guidelines include the following elements:

(1) A definition of key organization and administration terms;

(2) A list of information to be provided by applicants in written form and orally during the site visit; and

(3) The acceptance criteria for the utility's OAP.

The Appendices to the guidelines include:

(1) Instructions on how to present the utility's organization charts in a standardized manner (Appendix $A$ ); and

(2) Key definitions from appropriate ANSI/ANS standards relevant to the preparation of the OAP (Appendix B). 


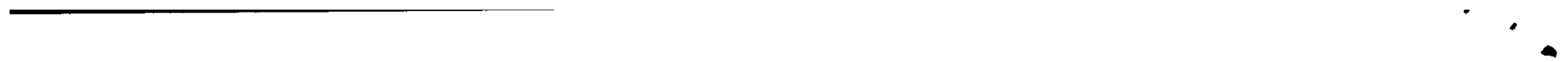




\subsection{DEFINITION OF TERMS}

\subsection{Organizational Levels of the Applicant}

Safety-relevant aspects of organization and administration may appear at any of up to three major organizational levels: the overall utility, the nuclear level, and the plant.

\subsubsection{The Utility Level}

The utility level is the headquarters level of the owner organization that will be licensed to operate the nuclear plant. The nuclear aspects of the utility level include those components (line and staff units) which deal with the nuclear level (as defined below) or the nuclear plant. Other aspects of the organization (e.g., customer billing) need not be discussed in the plan, although they should be depicted on the utility level organization chart in accordance with the guidelines in Appendix $A$.

\subsubsection{The Nuclear Level}

Many utilities have a special component, such as a nuclear division, that deals with all nuclear related activities but is broader than a specific plant. This document refers to that component, where it exists, as the nuclear level. The NRC does not imply that this level should exist in any applicant's organization. If the level does exist, it should be distinguished in the responses to these guidelines. Aspects to be covered in the plan include the major work groups within the nuclear level and the relationship of the proposed plant organization with the nuclear level. The plan should carefully distinguish those organizational components or resources which deal only with the proposed plant from those which are shared with other plants. The written submission should describe the proportion of time expected to be allocated to the proposed plant for any shared resources.

\subsubsection{The Plant Level}

The aspects of the plant level organization to be described in the written plan include major work groups within the plant and important relationships with entities outside the plant, especially other levels of the utility (e.g., corporate technical staff).

\subsection{Organization and Administration}

Organization refers to the formal structure of the allocation of work to be performed by particular units and by individuals with specific capabilities. Each applicant organizes the work to be performed. In other words, each applicant groups related activities into meaningful units for administrative purposes and then groups units into larger components. Administration refers to how an applicant controls the activities of the units, coordinates their action, and helps improve their performance. The four categories of organization and administration used in these guidelines are defined as follows: 
(1) Organization of work;

(2) Policies or procedures;

(3) Staffing; and

(4) External relationships.

\subsubsection{The Organization of Work}

The organization of work refers to the major assignments of tasks to positions or units within the organization, and the formal reporting relationships from one unit or position to another. It also includes the authorities of formal entities which incorporate elements from several administrative units such as standing committees and review groups.

\subsubsection{Policies or Procedures}

Policies or procedures refers to formal statements of activities to be carried out by the organization. Policies are the most formal and the most general; procedures are more specific statements of the correct manner of carrying out an activity. Policies or procedures are usually written down in formal documents and used by management to direct and control organization activities.

\subsubsection{Staffing}

Staffing refers to the required number of personnel in specified units, recruitment of personnel, individual qualifications, training, retention, and performance appraisal.

\subsubsection{External Relationships}

External relationships refers to individuals, groups, units, and organizations outside the utility (such as consultants, contractors, vendors, professional societies, other utilities, and various regulatory agencies) providing services, information, or expertise to the applicant. 


\subsection{INFORMATION TO BE PROVIDED BY APPLICANTS}

This section lists specific items that should be addressed by the applicant in the written plan and during the site visit. The items are organized by the four categories of organization and administration. The applicant may address all items in writing and in any order. However, several items may be presented instead during the NRC site visit, as noted in each section. The applicant should provide an index to show where each item is addressed in the plan. It is recommended that the applicant respond to the items in the order of the Guidelines for an efficient and thorough review.

References to other documents are encouraged, both to avoid duplication and to highlight the relationships between this OAP and other documents the applicant may be submitting to the NRC. Reference may also be made to NRC regulations, regulatory guides, ANSI standards, utility policy manuals, and other relevant documents.

\subsection{The Organization of Work}

For each relevant organizational level (utility, nuclear, plant), the applicant should provide:

3.1.1 An organization chart showing the title of each unit (e.g., divisions, departments, groups); the title of each manager or supervisor (e.g., VP Nuclear, maintenance superintendent); and each position within each unit (e.g., radwaste technician, reactor operator). At the utility level, the chart should include units responsible for fossil as well as nuclear plants, and any administrative, technical, or other groups which have responsibilities for nuclear plants. Appendix A provides detailed guidelines for preparation of organization charts.

3.1.2 A description of any standing committees, audit groups, matrix relationships, or other groups not normally shown on an organization chart bu. " entialty affecting nuclear activities Tidentify group members by their position on the organization chart);

3.1.3 A description of the duties and responsibilities (include any responsibilities for facilities other than the proposed plant) of each unit or position shown on the organization chart or listed in response to 3.1 .1 and 3.1 .2 ;

3.1.4 A description of any special organizational forms (e.g., provisions for establishing project teams or formal meetings) used to promote coordination across units at the same level and between line units (e.g., plant operations) and staff units (e.g., corporate engineeringl;

3.1.5 A description of any special organizational forms designed to control activities; 
3.1.6 A description of any special organizational forms devoted to planning or otherwise improving operations;

3.1.7 A description of any special organizational forms designed to identify possible non-normal operating conditions and plan responses;

3.1.8 A description of the organizational units and positions that will implement the test program;

3.1.9 A description of the next in command for each manager or supervisor (this may be discussed orally during the site visit);

3.1.10 The applicant should discuss how the organization of work for the utility, the nuclear level (if applicable), and the plant fit together into a consistent overall plan (this may be discussed orally during the site visit).

\subsection{Policies or Procedures}

For each organizational level (utility, nuclear, plant), the applicant should describe:

(Those policies or procedures pertinent to the staffing may be discussed in response to Section 3.3.)

3.2.1 General administrative policy manuals, together with table of contents from each. (Note: It is not usually necessary to include the manuals per se; the NRC organization and administration reviewers will be interested only in the scope of the manuals);

3.2.2 Policies or procedures (e.g., those detailing rewards or sanctions) designed to control the behavior of units as opposed to individuals;

3.2.3 Policies or procedures used to promote coordination across units. (Note: These policies or procedures may be presented orally during the site visit);

3.2.4 Policies or procedures for soliciting and evaluating suggestions from managers and employees outside of formal reporting channels;

3.2.5 Applicable safety standards established by the applicant, methods of assessment, and formal provisions to inform unit members of their safety performance (include any of the Institute of Nuclear Power Operations' nuclear plant performance monitoring indicators that will be used by the applicant);

3.2.6 Policies or procedures for long-range planning or other means of evaluating and improving the operations of units or the organization as a whole (as opposed to individuals); 
3.2.7 In addition, the applicant should discuss any set of policies or procedures for coordinating across the utility, nuclear level (if applicable), and plant levels (this may be discussed orally during the site visit);

3.2.8 The applicant should discuss how the policies or procedures for the utility, nuclear, and plant levels fit together into a consistent overall plan (this may be discussed orally during the site visit);

3.2.9 Any major instruments, equipment, and/or related resources (e.g., centralized data banks, tracking systems, and computer programs) used to determine the current status of activities;

3.2.10 Any major instruments, equipment, and/or related resources for promoting necessary communication across positions, units, and shifts within the utility level, the nuclear level (if applicable), and the plant;

3.2.11 Any major special systems for detecting and evaluating potential improvements in operations and safety;

3.2.12 Any major instruments, equipment, and/or related resources for promoting necessary data sharing across the utility, the nuclear division (if applicable), and the plant;

3.2.13 How the information systems for the utility, nuclear, and plant levels fit together into a consistent overall plan (this may be discussed orally during the site visit).

\subsection{Staffing}

For each organizational level, the applicant should describe or provide reference to:

(Policies and procedures for staffing may be included in this section.)

3.3.1 The skills, education, training, and experience requirements (qualifications requirements) for each manager and supervisor;

3.3.2 A listing of the skills, education, training, and experience of managers and supervisors and their backups who are al ready selected to occupy the positions (if hired at present);

3.3.3 Recruitment plans for unfilled positions, including the schedule relative to fuel loading;

3.3.4 A discussion of reward-incentive programs or other provisions to reinforce and encourage safe performance; 
3.3.5 A discussion of sanctions available to each unit (e.g., dismissal, imposition of fines, suspension) (this may be discussed orally during the site visit);

3.3.6 A description of policies or procedures for identifying and developing managers and supervisors for positions of higher authority and responsibility, including provisions for training, retraining, job transfer, temporary assignment, and career paths at each organizational level (this may be discussed orally during the site visit);

3.3.7 A detailed description of policies or procedures concerning the extent and nature of the participation and performance evaluation for $\mathrm{plant}$ operating and technical personnel in the initial test program;

3.3.8 How the personnel systems for the utility, nuclear, and plant levels fit together into a consistent overall plan (this may be discussed orally during the site visit).

\subsection{External Relationships}

For each organizational level, the applicant should describe provisions for:

3.4.1 Any important relationships with external resource groups (e.g., contractual relationships with consultants, long-term support by an NSSS vendor);

3.4.2 Replacing contractual and vendor support with employees of the owner organization, including a schedule for the transition;

3.4.3 Any audit and review procedures carried out by external entities;

3.4.4 Any major external sources of information or other external aids to long-range planning and potential improvements in operations;

3.4.5 Any major special systems for detecting, tracking, and responding to external requirements and requests (e.g., by regulators, INPO, vendors).

3.4.6 How the external support provisions for the utility, nuclear and plant levels fit together into a consistent overall plan (this may be discussed orally during the site visit); 


\subsection{ACCEPTANCE CRITERIA FOR GUIDELINES}

The acceptance criteria in these guidelines follow the four main sections of the guidelines themselves: (1) the organization of work, (2) policies or procedures, (3) staffing, and (4) external relationships. There are two types of acceptance criteria. First, there are criteria for completeness, rationale, and achievability.

The NRC assessment of overall organization and administration is based on analysis of the written OAP submission of the utility, supplemented by oral statements obtained during interviews with the utility staff.

OAPs are acceptable if they are judged hy the assessment team to be an adequate hasis for safely operating a nuclear power plant. The burden of proof is on the applicant to demonstrate that the OAP is adequate.

The basis for a determination of adequacy is if an OAP: (1) is complete, (2) has a rationale for the elements within it, and (3) is achievable. Completeness refers to whether applicants have considered the issue defined in the Guidelines and have made a response of some sort. Rationale refers to whether applicants can justify the choices made. Achievable refers to whether the OAP is integrated with the rest of the applicant's organization and administrative practices and is understood by the key managers involved such that OAP is feasible and can be implemented. These terms are further defined below.

\subsection{Completeness}

This criterion addresses whether applicants have at least considered all the items in the Guidelines. Completeness also means that all guideline items required in the OAP are included and that all prescriptive guidelines $i$ tem are met. The worksheets appended to this workbook identify the required and prescriptive items by checks in the "Required" column.

The prescriptive criteria are hased on current NRC rules, regulatory guides, Branch Technical Positions, and/or ANSI standards. These items have been taken from the July 1981 Standard Review Sections 13.1.1, 13.1.2, and 13.5.1. Thus, they reflect consistent NRC policy on these issues.

It should be emphasized that the completeness criterion does not mean that applicants must have every organizational or administrative feature identified in the worksheets. With the exception of the required and prescriptive items discussed above, the completeness criterion only means that they have given due consideration to each item. Their reason for not considering certain items or proposing alternative approaches is considered under the rationale criterion discussed below. 


\subsection{Rationale}

This criterion addresses why applicants propose a particular type of organization or pattern of administration. In general, rationales for most decisions will be obtained during the site visit rather than from the OAP submittal. Documenting the reason for every decision is unrealistic. The rationale for many decisions will be apparent. However, at a minimum, applicants should show they have given careful consideration to the design of the major features of their proposed organization and administrative system. There are many reasons that applicants may give for choices they have made, and many of them will have been made with less than perfect information. Each utility faces unique circumstances calling for managerial judgment. Acceptable types of rationale that utilities may use in defending their plans are outlined below.

- Regulation. Some design aspects of the plant or utility may be subject to requirements or regulations that limit the discretion of utility managers. NRC requirements and regulatory or legislative requirements derived from any federal or state agency should be cited, where applicable.

- Study. Some design aspects may be supportable by reference to a well-designed and executed study. A study directed specifically to the organization or management aspect in question for a nuclear facility may be cited, or a study dealing with some other industry or management aspect may be acceptable in some cases. In the latter instance, the review team will need to consider whether the study is truly relevant to the issue at hand.

- Formal Reasoning. Aspects of the OAP may be supported by formal reasoning. This reasoning may involve analogies derived from practices elsewhere (e.g., other nuclear power plants, non-nuclear facilities, etc.). In any event, applicants should be able to explain why these situations are relevant to the proposed plant.

- Managerial Judgment. Some aspects of the proposed design cannot be supported on the basis of regulations, empirical data, or formal reasoning. Unique conditions call for the professional preferences of managers and supervisors. Even in these cases, management should be able to provide a logical argument for why they made the decision, including why they discarded other al ternatives.

Some rationales may, in fact, suggest that respondents do not know why a particular choice was made nor the advantages or disadvantages of the choice. For example, rationales based solely on cost constraints, or "company philosophy," or orders from a "higher authority" are not sufficient. Generally these denote a condition where individuals are unlikely to know why, how, or if their actions contribute to plant safety. Repetition of a weak rationale may be considered a strong signal that the proposed $p l a n$ itself is neither complete nor achievable. 
Reviewers will have to exercise judgment about whether particular rationales are acceptable.

\subsection{Achievability}

This criterion addresses two main issues. Will the OAP provide the level of resources, control, coordination, and longer-term improvements desired? Is the proposed OAP properly integrated between the corporate and plant levels, and horizontally among the plant organizational components so as to achieve the intent of the OAP?

The second aspect of this criterion is whether various features of the OAP are understood by the key managers and staff involved. Without this understanding, the OAP cannot be effectively implemented and safe plant operation will be jeopardized.

One aspect of organization and administration may be a substitute or a complement to another. Therefore, not every section of an applicant's OAP will be equally detailed and the plan should describe such interrelationships among aspects of organization and administration where appropriate. The plan should also point out how the emphasis on the four major aspects of organization and administration differ by level of the organization (e.g., an applicant should submit an organization chart for each level) and by specific function (e.g., quality assurance, fire protection, radiation protection, physical security, safeguards, emergency response).

While many judgments about the completeness of the plans can be made from the written plan, final judgment about compliance with prescriptive standards, adequacy of the applicants' rationale for various aspects of the OAP, the achievability of the OAP, and the overall adequacy of the applicant's OAP will be determined following a site visit and/or additional direct contact with the applicant. Ultimately, acceptance must be judgmental, but an accompanying workbook will be used to provide guidance to the NRC staff. The workbook is intended to enable NRC staff to make judgments on acceptance in a consistent and valid manner. The workbook itself provides more detail on the process for determining the adequacy of the OAP.

\subsection{The Organization of Work}

THE PLAN IS COMPLETE IF:

4.4.1 Organization charts are presented for the overall utility, the nuclear division (if applicable), and the plant. (The applicant should follow the format described in Appendix $A$ of this document, including the minimum number of persons to be assigned to each organizational element, the minimum number of persons assigned to common or duplicated positions, and the number and composition of operating shift crews.) 
4.4.2 Organization charts for the utility, nuclear level (if applicable), and/or the plant:

- Depict all plants (fossil as well as nuclear) operated by the utility and any technical, administrative or other off-site group that provides service to plants other than the plant for which the application is being made;

- Provide organization charts for all other nuclear plants operated by the owner organization;

- Enumerate all utility units and officers to whom there is a direct reporting relationship from the nuclear level (if applicable) and the plant;

- Provide modified organization charts where there is more than one generating plant at the station, indicating changes and additions as new capacity is added to the site;

- For persons with duties at or concerning the proposed plant, reference descriptions of any proposed sharing of persons with other facilities (whether or not those other facilities are licensed by the NRC); and reference descriptions of the duties applicable to other facilities, and the proportion of the time individuals will routinely be assigned to the other facilities.

4.4.3 It describes standing committees, matrix relationships, and/or units (including those for safety review) and references appropriate sections of the quality assurance plan for auditing.

4.4.4 It describes the goals, duties, and responsibilities for each unit position identified in response to 3.1 .1 and 3.1.2;

4.4.5 It describes any special organizational arrangements for coordination (across units and levels), control, planning, and improving performance;

4.4.6 It describes any special arrangements for identifying non-normal operating conditions and planning responses (may reference safety review);

4.4.7 It describes the next in command for each major position;

4.4.8 It enumerates the units and/or functions considered important for safe operations;

4.4.9 It identifies and describes the organizational groups responsible for implementing the initial test program; 
4.4.10 It describes the linkages among and across the managers responsible for nuclear operations and groups or units of the utility, the nuclear level, and the plant.

4.4.11 It identifies on organization charts all contractor and private organizations that may be requested to provide technical assistance to the utility, nuclear level, and plant;

ADDITIONALLY THE PLAN MEETS THE FOLLOWING PRESCRIPTIVE CRITERIA IF;

4.4.12 It follows the Standard Review Plan (July 1981) by including descriptions of the authority and responsibilities of positions or units corresponding to the following:

For the overall utility or nuclear level (cf. SRP 13.1.1, Section I.B.):

- Nuclear, mechanical, structural, electrical, thermal-hydraulic, metallurgical and materials, and instrumentation and controls engineering;

- Prant chemistry;

- Health physics;

- Fueling and refueling operations support;

- Maintenance support;

- Operations support;

- Quality assurance (may reference quality assurance plan);

- Training;

- Safety review;

- Fire protection (may reference fire protection plan);

- Outside contractual assistance;

- Technical services and backup support for the operating organization;

- Radiological protection;

- Emergency response (may reference the emergency response plan);

- Other functional areas which the applicant may propose. 
At the plant level (cf. SRP, Section 13.1.2):

- Overall plant management;

- Operations supervision;

- Operating shift crew supervision;

- Shift technical advisors;

- Licensed operators;

- Non-licensed operators;

- Technicar supervision;

- Radiation protection supervision (may reference radiation protection plan);

- Instrumentation and controls;

- Equipment maintenance supervision;

- Fire protection supervision (may reference fire protection plan);

- Quality assurance supervisor (may reference quality assurance plan);

- Other functional areas which the applicant may propose.

4.4.13 It establishes written descriptions of the authority and responsibility for managers of the functional areas corresponding to 4.4.12;

4.4.14 It provides for clear management control and effective lines of authority and communication among the organizational units involved in management, operation, and technical support;

4.4.15 It provides a description of defined lines of reporting responsibilities (accountability) between each unit and the unit or official to which it reports;

4.4.16 The responsibilities and authorities of operating organization personnel conform to the requirements of:

- ANSI N18.7, Section 5.2, "Rules of Practice," instructions pertaining to personnel conduct and control, including consideration of job-related factors which influence the effectiveness of operating and maintenance personnel, including such factors as number of hours at duty station, availability on call of professional and supervisory 
personnel, method of conducting operations, and preparing and retaining plant documents;

- Section 4.4, "On-Site Review," as endorsed by Regulatory Guide 1.33 (Revision 2, February, 1978), "Quality Assurance Program Requirements (Operation)" which strongly endorses Section 4.4 of ANSI N18.7 concerning onsite reviews of the operating organization by plant supervisory personne1;

- ANSI N18.1, Section 3.2, "Operating Organization," as endorsed by Regulatory Guide 1.8 (Revision 1) "Personnel Selection and Training," which deals with education and experience requirements for NPP personnel;

- TMI Action Plan item 1.C.3, "Operations Procedures--Shift Supervisor Responsibilities" of NUREG-0694, indicating that the responsibilities of the shift supervisor shall clearly establish the command duties of the shift supervisor and emphasize the primary management responsibility for the safe operation of the plant.

4.4.17 It shows that the functional areas of radiation protection, quality assurance, and training are independent from unwarranted diversion from functional responsibilities;

4.4.18 It indicates sufficient managerial depth to provide qualified backup in the event of the absence of incumbents.

\subsection{Policies or Procedures}

THE PLAN IS COMPLETE IF :

4.5.1 It describes or provides reference to policies or procedures for: General administration (complete with table of contents);

- Controlling units;

- Promoting integration (coordination) among and across levels and units;

- Anticipating and preventing potential problems (may reference safety review documents);

- Long-range planning and improving unit operations.

4.5.2 It describes safety standards, methods of assessment, and provisions to provide feedback;

4.5.3 It indicates that all organizational and administrative procedures important to safe operation of the plant are clearly described in written policy or procedure manuals; 
4.5.4 It provides that procedure manuals shall be readily accessible to a11 plant and offsite personnel who supervise or perform procedures described in such manuals;

4.5.5 It provides for written policies or procedures to ensure communication among units regarding tasks actually or potentially involving more than one organizational unit;

4.5.6 It provides for written policies or procedures for periodic planning for improved operation;

4.5.7 It provides for written policies or procedures for evaluating possible departures from normal or desired operating conditions, and defining appropriate responses in advance of such conditions;

4.5.8 The plan describes instruments, equipment, and related resources for:

- Determining the status of activities;

- Data sharing within and across positions, units, shifts, and organization levels;

- Planning (including budgetary planning);

- Detecting and reevaluating potential improvements.

4.5.9 The plan includes provisions for information tracking systems immediately accessible to managers of all safety-related activities;

4.5.10 It provides a monitoring system for determining all externally imposed requirements and for reporting these to responsible managers;

4.5.11 It provides for a monitoring system for ascertaining compliance with all externally imposed requirements;

4.5.12 It provides for an audit and review system to monitor compliance of internal policies or procedures (may reference safety review plan).

\subsection{Staffing}

THE PLAN IS COMPLETE IF :

4.6.1 It describes formal qualifications for all positions on the organization charts as per responses to Sections 3.1.1 and 3.1.2;

4.6.2 It provides (normally in an appendix) an enumeration of the education, training, and experience of those occupying positions specified in responses to Sections 3.1.1 and 3.1.2; 
4.6.3 It describes:

- Reward/incentive programs;

- Sanctions available to each unit;

- How the personnel systems at different levels of the organization fit together.

4.6.4 It describes (or references another section) policies or procedures for:

- Identifying and developing personnel;

- Training and retraining of personne 1;

- Utility personnel participation in and evaluation of the test program.

ADDITIONALLY THE PLAN MEETS THE FOLLOWING PRESCRIPTIVE CRITERIA IF:

4.6.5 The staffing $\mathrm{plan}$ provides a schedule relative to initial fuel loading for having sufficiently trained, qualified staff to implement the initial test program and for all activities important to the safe operation of the plant, including the positions involved in preoperational and start-up tests, as well as those who will be involved in full-power operations. (At the PSAR stage, it is recognized that many staffing details will not have been finalized. At the FSAR stage, this section should include position titles, applicable operator licensing requirements, and the total number of people required to man each shift for all combinations of plants proposed to be at the site in either operating or cold shutdown modes. Shift crew staffing plans unique to refueling operations should also be described, as well as the proposed means of assigning shift responsibility for implementing the radiation protection and fire protection programs on a round-the-clock basis) (cf. SRP 13.1.2, Sections I.C., I.E.);

4.6.6 It provides for written position descriptions for all safetyrelated positions at all levels of the organization (cf. SRP 13.1.2, Section I.C.);

4.6.7 It describes a formal performance appraisal system;

4.6.8 It includes provisions for determining the training needs of individual staff members and for scheduling their participation in training programs;

4.6.9 It demonstrates that the utility's own technical staff should be utilized in the initial test program to the maximum extent practicable. (There should be an indication that (a) participants in the test program will receive plant-specific training/ 
indoctrination in the administrative controls for the test program prior to the start of testing and (b) the level of staffing should be adequate based on the reviewer's judgment.) (cf. SRP 13.1.1, Section II. B.8.)

\subsection{External Relationships}

THE PLAN IS COMPLETE IF:

4.7.1 It describes important long-term relationships with external resource groups not shown on the organization chart le.g., contractual relationships with consultants; provisions for long-term support by an NSSS vendor);

4.7.2 It indicates those functions currently performed by external support organizations or personnel at the time of the plan's submission which will ultimately be performed by employees of the owner organization and describes the schedule for implementation of this transition for the above functions;

4.7.3 It describes audit and review procedures to be used by external groups (may reference quality assurance plan);

4.7.4 It describes major external sources of information or other external aids to long-range planning and potential improvements in operations. 
APPENDIX A

ORGANIZATION CHART GUIDELINES 


\title{
APPENDIX A
}

\author{
ORGANIZATION CHART GUIDELINES
}

The organization charts required by Item 3.1 .1 should be prepared in a standardized manner using the guidelines below. This standardization of organization charts will greatly facilitate the consistency of NRC reviews.

\section{A. 1 GENERAL ORGANIZATION CHART GUIDELINES}

Each organization chart should be comprised of the basic elements defined below. An example chart demonstrating the use of these concepts is provided in Figure 1 (this example is for illustrative purposes only).

- Boxes should be used to identify managers and supervisors. The job titles of managers and supervisors should be placed in the boxes. Typical examples would be plant manager, shift supervisor, and electrical foreman.

- Sticks (1 ines attached to the boxes) should be used to identify people who are not managers or supervisors. Examples in the typical plant would be secretaries, direct workers, and staff assistants. The job title of the position should be written parallel to the stick. The sticks should be attached to the appropriate supervisory box. One stick may be used for all people with the same job title who report to the same manager or supervisor.

- Job Titles should be used to identify the type of position represented by the boxes and sticks. If the job title does not convey the nature of the work responsibilities, a brief description should be added in parentheses alongside the job title as appended. Standard abbreviations may be used.

- Numbers should be used to identify the number of people with the same exact position in the organization. For example, the position of shift supervisor should be represented by a single box and the number of shift supervisors filling the position should be placed in parentheses following the job title.

- Lines are used to connect the boxes to represent the lines of formal authority. To clearly represent these 1 ines of authority, the chart should start with the highest level and represent the organization as a pyramid of boxes and sticks connected with vertical lines as shown in the attached example. For people reporting off-site, the lines of authority and the appropriate off-site supervisor should be included.

A.1.1 Footnotes should be used to identify job titles which may be filled by contract employees, part-time employees, workers with 


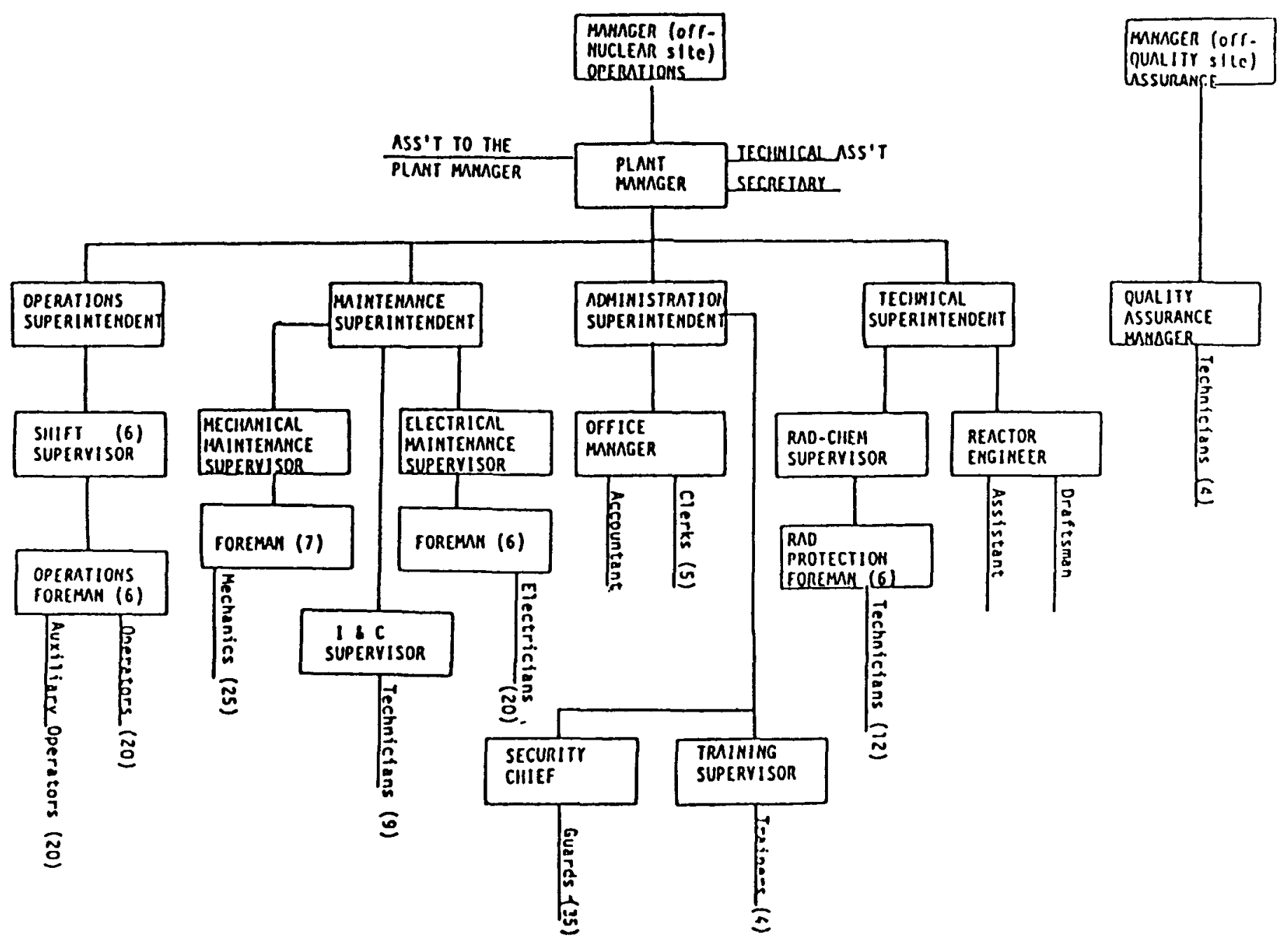

Figure 1

Sample Organization Chart (to show form only) 
responsibilities for more than one plant or job, or other unusual conditions which result in less than full-time effort in the position described.

A.1.2 Either on the chart or in a separate list, the plan should identify any standing committees (for example, fire protection, safety review) and which persons (job titles) are expected to serve on the committees.

A.1.3 Organizations with a matrix structure should prepare two organization charts for each section having a matrix organization. The two charts should reflect the organization as viewed from each side of the matrix. Any matrix organization plans should devote extra discussion to issues of coordinating across sides of the matrix in the policy discussion sections (see Sections 3.1.6 and 3.2.3 of this document). 


\section{A.2 GUIDELINES FOR ORGANIZATION CHARTS AT PARTICULAR LEVELS OF ORGANIZATION}

\section{A.2.1 Utility}

More detail is needed for those aspects of the overall utility which are closely linked to the nuclear organization than for other parts. For example, the customer service divisions are unlikely to have important impacts on nuclear operations. The applicant should decide which aspects of the overall utility are not closely linked to nuclear operations. For those aspects, it will generally be sufficient to indicate the most senior official below the CEO responsible for that part of the utility, along with the name of that division, department, or other part of the organization. Some utilities provide important engineering, construction, and maintenance services through centralized departments, or separate subsidiaries. In these cases, the detail provided for these sub-units at the overall utility level should be comparable to that provided at the nuclear level if these services had been located within a nuclear level. Utilities with joint venture partners in a proposed nuclear plant should indicate the nature of formal reporting relationships with such partners in the overall utility section in order for the NRC to get a complete understanding of the owner organization.

\section{A.2.2 Nuclear}

In this section, detailed charts should be provided for every aspect of this level of the organization (if the applicant has this level--see Section 2.1.2 of this document). If certain groups or persons deal only with the proposed plant (rather than a collection of plants), this should be indicated. The total number of plants dealt with by the nuclear organization should be indicated.

\section{A.2.3 Plant}

The organization chart for the proposed plant should include every authorized job position within the plant, all formal reporting relationships within the $\mathrm{plant}$, and formal relationships between $\mathrm{plant}$ personnel and the nuclear level or overall utility officials. 


\section{APPENDIX B}

UTILITY GUIDELINES DOCUMENTS FROM ANSI/ANS 


\section{APPENDIX B}

\section{UTILITY GUIDELINES DOCUMENTS FROM ANSI/ANS}

In this appendix, the scope of ANSI/ANS-3.1 and ANSI/ANS 3.2 are described, and a number of useful definitions are reproduced. These terms are used in the same way in the body of the present guidelines document.

\section{B.1 ANSI/ANS 3.1: SELECTION, QUALIFICATIONS, AND TRAINING OF PERSONNEL FOR NUCLEAR POWER PLANTS}

ANSI/ANS-3.1 describes criteria for the selection, qualification, and training of operating personnel for nuclear power plants. Criteria are provided for managers, supervisors, professional technical, operator technical maintenance, engineering and technical support, and independent review personnel. Training requirements are al so specified for those personnel required to be licensed by the NRC and for those personnel not requiring NRC licenses.

\section{B.1.1 Definition of Terms}

The following definitions are reproduced from pages 1 and 2 of ANSI/ANS-3.1. These terms are used the same way in this guidelines document.

- Nuclear power plant: any plant using a nuclear reactor to produce electric power, process steam, or space heating.

- Off-site personnel: those personnel providing technical and operational support and not reporting directly to the plant manager. These personnel may be located on- or off-site.

- On-site personnel: those personnel that are assigned to the site as their normal work location.

- Owner organization: the organization, including the on-site operating organization, which has overall legal, financial, and technical responsibility for the operation of one or more nuclear power plants. This includes contracted personnel.

- Shall, should, and may: the word "shall" is used to denote a requirement; the word "should" to denote a recommendation; and the word "may" to denote permission, neither a requirement nor a recommendation.

\section{B.1.2 Additional Terms from Text of ANSI/ANS-3.1}

- Managers . . are those who are assigned broad responsibilities for direction of major aspects of a nuclear power plant. This - . generally includes the plant manager (plant superintendent, or other title), his or her line assistants, if any, and the principal members of the operating organization reporting directly to the plant manager. ... 
- Supervisors are persons principally responsible for directing the actions of operators, technicians, or maintenance personnel.

Those positions usually designated as intermediate and first-line supervisors are included in this category ( $p .3)$. 


\section{B.2 ANSI/ANS-3.2 DRAFT, APRIL 1981, ADMINISTRATIVE CONTROLS AND QUALITY ASSURANCE FOR THE OPERATIONAL PHASE OF NUCLEAR POWER PLANTS}

This standard provides requirements and recommendations for administrative controls and quality assurance programs for NRC 1 icensed nuclear power plants.

\section{B.2.1 This ANSI/ANS standard provides additional definitions of terms:}

- Audit: a planned and documented activity performed to determine by investigation, examination, or evaluation of objective evidence the adequacy of and compliance with established procedures, instructions, drawings, and other applicable documents, and the effectiveness of implementation. An audit should not be confused with surveillance or inspection activities performed for the sole purpose of process control of product acceptance.

- Review: a deliberately critical examination, including observation of plant operation, evaluation of audit results, procedures, certain contemplated actions, and after-the-fact investigations of abnormal conditions.

B.2.2 The general standard 3.4.1 for on-site operating organizations from ANSI/ANS-3.2 is reproduced below (see p. 25 of ANSI/ANS-3.2).

A number of factors influence administration in its decision regarding the establishment of an on-site operating organization. These include the owner organization's established staffing policies, the physical size and complexity of the nuclear power plant, the number of units, the extent of assistance provided by off-site technical support organizations, the extent of reliance on consultants, and the availability of qualified personnel from other sources to assist in activites, such as initial start-up, refueling, maintenance, or modification work. It must be expected that a nuclear power plant's on-site operating organizations will change with time to reflect relevant industry experience, changes in federal regulations, and changes in the factors listed above.

Administration shall periodically reassess the adequacy of the on-site operating organization in light of such considerations and shall assure that necessary changes are made in a timely manner.

\section{B.2.3 Section 5.1 of ANS/ANSI-3.2 (pp. 43-44) Program Description}

The total program for providing administrative controls and quality assurance during the operational phase may be described in many diverse documents. For example, operating procedures may be compiled in one manual, maintenance procedures in a second manual, and qual ity assurance procedures in a third. It is not intended that all source documents be compiled in one master document. However, a summary document should be compiled by each owner organization to identify the sources, to index such source documents to the requirements of this Standard, and to provide a consolidated base for description of the program. The owner organization 
shall identify in the program description those structures, systems and components to be covered by the program, and the major organizational units and their responsibilities. The program shall provide control over activities affecting the quality of the structures, systems, and components to an extent consistent with their importance to safety. The program shall take into account the need for special controls, processes, tests, equipment, tools, and skills to attain the required quality and the need for verification of quality by inspections, evaluation, or test.

\section{Rules of Practice}

The owner organization shall establish rules and instructions pertaining to the conduct and control of on-site activities such that affected personnel are provided with a clear understanding of operating philosophy and administration policies, as well as methods and techniques for performing required work. 
NUREG/CR -4125

PNL -5374

BHARC-300/85/002

VOL. 1

REV. 1

RX

\section{DISTR IBUTION}

OFFSITE

U.S. Nuclear Regulatory Commission

Division of Technical Information and Document Control

7920 Norfolk Avenue

Bethesda, MD 20014

20 Peter McLaughlin

Division of Human Factors Safety

Office of Nuclear Reactor Regulation

U.S. Nuclear Regulatory Commission

Mail Station AR-5200

Washington, D.C. 20555

ONSITE

Pacific Northwest Laboratory

2 R.D. Widrig

1 R.V. Badalamente

2 Publishing Coordination

5 Technical Information

Human Affairs Research Centers

25 J.A. Thurber

10 J. 01 son

1 R.N. Osborn

1 P.E. Sommers

1 W.L. Rankin

2 HARC Central Report File/B. Keen 